\title{
Judicial Decision-Making within Political Parties: A Political Approach
}

\begin{abstract}
:
How do German intra-party tribunals manage internal conflicts? More specifically, why do they accept some cases for trial but reject others? Required by law to strictly adhere to procedural rules, German intra-party tribunals are designed to insulate conflict regulation from politics. Meanwhile research on judicial politics highlights the role of political and strategic considerations in accepting cases for trial. We develop a theory that emphasizes tribunal's political concerns such as winning elections that go beyond procedural considerations. We test our hypotheses with a mixed-effects logit model on a novel data set covering 1088 tribunal decisions in six German parties from 1967 until 2015. Our findings indicate that political factors exert a strong effect on tribunal case acceptance. Tribunals are more likely to accept cases after losing votes and government office. Moreover, they dismiss cases more easily when their parties display relatively high policy agreement.
\end{abstract}

Keywords: Party Conflict Regulation, Party Elites, Party Members, Political Parties 
The ability of parties to manage and ultimately resolve internal conflict is not only vital for their organizational survival but also to fulfill their functions within the political system. To do so, parties adopt different kinds of conflict regulation mechanisms that can range from hierarchical mechanisms controlled by the party leadership to non-hierarchical mechanisms controlled by actors independent of the leadership (Bolleyer et al. 2017: 836). Despite the growing literature dealing with different sources of party conflict ${ }^{1}$, we know only little about the nature of procedures that organizations adopt to address this important challenge on a day to day basis. ${ }^{2}$ This paper investigates one important type of procedure, namely German intra-party tribunals, quasi-judicial bodies established within party organizations to resolve internal disputes and designed to mirror national legal structures. In order to function effectively, they are supposed to be neutral, independent and fair. ${ }^{3}$ Indeed parties often claim to emulate these norms in their conflict regulation procedures, yet as Rahat points out "...these organs are suspected (often with reason) of being partial." (2013: 141). Concerns about the impartiality of judicial bodies derives from a long literature on the partisan leanings of state and national courts in the United States (Hein and Ewert 2016; Kastellec and Lax 2008), which provides strong evidence that political factors affect the decisions of state courts, with important repercussions for the operation of these bodies in intra-party settings.

This paper takes a step back and investigates the importance of political considerations in the decisions of tribunals to accept or reject cases. Evidence of impartial judgments may mask legally neutral tribunals' avoidance of politically sensitive cases 'on formal grounds'. Our theoretical argument proposes that party tribunals indeed accept or reject cases in line with "their political preferences or considerations regarding political appropriateness" (Hein and Ewert 2014: 70). Specifically, we link the likelihood of case acceptance to the core partisan goals of vote maximization, policy implementation and

\footnotetext{
${ }^{1}$ See, for instance, work on factionalism by Boucek 2009; 2012 or Zariskia 1965; on the internal dynamics in and evolution of new parties by Art 2011; Bolleyer 2013; Mudde 2007; or Müller-Rommel and Poguntke 2002 or on intra-party conflict linked to government participation and intra-party democracy, Bäck 2008; Deschouwer 2008; Giannetti and Benoit 2008; Maor 1992; Scarrow 2005 or Seeleib-Kaiser 2010.

${ }^{2}$ But see Gherghina 2014; Smith and Gauja 2010; Bolleyer et al 2017.

${ }^{3}$ Independent tribunals are not only common in democracies where they are required by law such as Germany, Czech Republic, Romania and Portugal (Biezen and Piccio 2003). We also find them in countries such as Norway and UK where intra-party matters are not made subject to legal regulation (Bolleyer at al 2018).
} 
office holding (Müller and Strøm 1999). Our theoretical framework provides insight into the extent to which tribunals use their power to advance central party goals rather than act as neutral dispute regulation mechanism even in settings where neutral decision-making is legally prescribed.

The German case provides a crucial advantage to a systematic analysis of our framework: all aspects of party tribunals are highly regulated by the German Party Law of 1967, which makes Germany a least likely case to find politicized judicial decision-making in intra-party settings and therefore constitutes a 'hard case' to test our framework. If we find politicized judicial decision-making in the highly regulated context of Germany it is highly likely to play an even stronger role in less regulated intra-party dispute mechanisms. Analyzing tribunal decisions across six parties and over nearly five decades, our findings support our central theoretical argument that German party tribunals follow a political logic when they consider whether to accept or reject cases. First, the greater the gains parties made at the last election, and hence the stronger their position towards internal challenges, the less likely cases are to be accepted. Second, tribunals operating in parties that are programmatically highly coherent are less likely to accept cases submitted to them. Third, if a party lost government (weakening the ability of the party to downplay conflict), tribunals are more permissive in the approval of cases.

This study makes three main contributions to existing research that go beyond the direct insights of our analysis. First, previous studies considered the impact of party goals on outcomes such as coalition formation (see Pedersen 2012) but, to our knowledge, did not apply them to questions of intra-party conflict regulation. Our approach thus investigates the role of party goals in a new area. Second, the study of intra-party tribunals, which allow both party elites and ordinary members to initiate cases, is insightful for the understanding of conflict regulation outside traditional hierarchical mechanisms controlled by party elites that impose solutions on actors and procedurally privilege one group of intra-party actors over others. Third, our research also has important normative repercussions. Research on intra-party democracy have focused on 'electoral mechanisms' (e.g. primaries) at the expense of its legal foundations, which is why intra-organizational mechanisms established by parties to protect their members' rights remain widely understudied (but see Biezen and 
Piccio 2013; Bolleyer et al 2015). Our findings not only undermine assumptions on the neutrality of tribunal decision-making but also raise the question whether it is possible to effectively transplant court structures into political parties as tribunals' positive effects on intra-party democracy and the electoral aims of parties are often difficult to reconcile.

\section{Politicization of Judicial Decision-Making}

An increasing number of political scientists (Stone Sweet 2000) and legal scholars (Hein and Ewert 2016; Kastellec and Lax 2008) study the politicization of judicial processes such as the appointment of judges and judicial review. In contrast, whether or not political considerations affect the initial selection of cases by tribunals have received less scholarly attention despite generally low acceptance rates in many legal systems (Mak 2015). Existing literature on case acceptance argues that court decisions generally are (co)determined by political influences such as judges' political party affiliation, policy preferences (Hein and Ewert 2016; Zorn and Bowie 2010;) and electoral politics (Joondeph 2008). In a classic study, Sheldon (1970) describes judges as 'politicians in robes' that do not systematically differ from other political actors. Politicized courts sort cases into acceptable and non-acceptable piles before even scheduling a hearing in clear opposition to the purely formal and procedural grounds on which case acceptance or rejection should be based (Provine 1980: 15).

Intra-party tribunals in charge of resolving conflicts between party members, often claim to emulate both the legal and supposedly neutral norms and procedures of public courts. Even when party statutes severely restrict tribunals' leeway to reject cases compared to public courts, we nevertheless expect that intra-party tribunals are similarly influenced by a political rather than a purely legal calculus when deciding whether to accept or reject cases. Further even if members of the party tribunal might be banned from holding any additional party office, they still have a vested interest in the success and survival of their organization. Thus, the question remains if Joondeph's (2008: 348) observation that the "determinants of judicial decisions, law and politics are in many respects inextricably intertwined" also holds in intra-party settings. 


\section{A Political Account of Tribunal Decision-Making: The Importance of Votes, Policy and Office}

We propose a new framework on tribunal decision-making based on the three main party goals of vote, policy implementation and office identified by Müller and Strøm (1999). Whereas some scholars stress trade-offs between the three goals parties usually pursue them simultaneously (Müller and Strøm: 12) and design their internal organization towards realizing these three goals (Harmel and Janda 1994; Borz and Janda 2018). Independent tribunals are supposed to solve intra-party conflict without being affected by these strategic party goals and thus their decisions might challenge if not undermine the party's peruse of these goal at times if the party regulations requires it. In contrast, our theoretical argument emphasizes that even if tribunals are designed to be independent, by strategically accepting or rejecting cases, can be directed towards the implementation of party goals and thereby contribute to organizational stability. We outline how each goal imposes its own constraints on the decision-making processes of the tribunals at different times.

\section{Vote Maximization and the Bypassing of Conflict}

The first goal that motivates parties' behavior is vote maximization with the aim to receive more votes than the other parties and thus win elections (Müller and Strøm 1999: 8). Achieving this goal is also vital to achieving the other two goals of policy and office. Therefore parties are most likely to reform both in terms of policy, personnel and organization if they underperformed in the latest election (Janda 1990: 5; Harmel and Janda, 1994). We can expect political pressures resulting from electoral underperformance to also affect how tribunals deal with cases submitted to them. These periods often involve debates around how internal processes (do or should) work, how decisions are made and what explained the vote loss. It becomes difficult for the weakened party to downplay or ignore conflict and mirroring the readiness to give in to demands of intra-organizational reform party elites - including tribunal members - might also be more permissive in the handling of the conflict. This suggests that after a loss of seats during elections, more cases should make it through the approval stage of intra-party tribunals. 
H1.1 (Vote Gain Hypothesis): Tribunals are more likely to accept cases the more a party's electoral performance declines.

Theorizing the repercussions of parties' vote aspirations, the timing of when intra-party conflict is handled is important. Clarke (2013) distinguishes between intra-party conflict occurring over the entire inter-electoral period and conflict that occurs in the months immediately prior to election day. With regard to the latter, he argues that the closer parties get to the next election the more likely they are to draw the media's spotlight and thus want to present themselves as unified. Furthermore, conflict closer to election day will be recalled by voters when going to the polls (Clark 2013). This is underlined by Traber et al (2013: 194) stating that "elections are likely to play an important role in the quest for party unity". Consequently, the portrayal of the party as divided can have a negative impact on its electoral prospects, which is why tribunals are incentivized to avoid dealing with cases close to election day. This leads to our second hypothesis:

H1.2 (Time to Election Hypothesis) Tribunals are less likely to accept cases the closer the next election.

\section{Policy: Policy Disagreement and Responsiveness to Intra-Party Conflict}

One of the main goals of parties is to maximize its impact on public policy (Müller and Strøm 1999: 7). But in order to do so effectively they need to present a coherent set of policies, as parties that appear divided over policies tend to lose elections (Greene and Haber 2014) and are less likely to get into government (Bäck 2008). The lack of a clear program often results from the lack of agreement over policy that might separate parties into competing factions (see for example the fundi-realo debate in the German Green Party, Burchcell 2002). Lack of agreement has repercussions for intra-party conflict regulation. Parties need to find a way to internally absorb conflict resulting from policy disagreement before it affects their performance at the ballot box. The more severely factions clash over policy and seek to weaken their opponents by formal and informal means, the more deeply involved tribunals become in managing these conflicts. Thus, in parties with lower policy agreement tribunals 
play a key role in keeping and resolving conflict internally by accepting more cases before policy clashes negatively affect the party's public standing. Conversely, we expect tribunals operating in parties with high policy agreement to wield greater freedom when deciding to ignore conflict to display an image of unity to the outside world. Tribunals of high policy agreement parties should accept fewer cases:

H2 (Policy Agreement Hypothesis): Tribunals in parties with high policy agreement accept fewer cases than tribunals in parties with low policy agreement.

\section{Office: Conflict Regulation Inside and Outside Government}

The last goal of parties identified by Müller and Strøm (1999: 5) is office. The successful holding of government office has important intra-organizational repercussions. When a government party is busy implementing its program, its attention shifts from organizational matters to the functioning of the party in public office (Katz and Mair 1995). Simultaneously, government participation often brings its share of frustration to those in the organization not involved in governing themselves, in terms of the compromises necessary in policymaking - especially in coalition governments - and the quite common decline in direct accountability of those running government to the organization outside (e.g. MüllerRommel and Poguntke 2002). This can fuel internal conflict and enhance the need for conflict regulation in a period during which the public display of such conflict might be particularly unwelcome. Therefore, while in the government a party might be keener and more able to downplay or ignore internal conflict as the display of unity is more important to assure the party's ability to effectively implement its program. Here tribunals can play a crucial role in supporting this display of unity by accepting fewer cases.

H3.1 (Government Party Hypothesis): Tribunals are less likely to accept cases when their party is in government than when it is in opposition.

As holding office raises incentives to downplay conflict, losing office usually triggers heightened internal debate about the reasons behind the setback and about the strategy to regain governmental control. Courtney (1995:262) shows that party authority weakens 
during opposition periods and intra-organizational challenges and reforms become particularly likely. For parties this is a chance for renewal (LeDuc 2001) and a possibility for the organization to reconnect with members and voters. These periods often include reforms that empower the members over party elites, which the latter might not have agreed to had they not lost office (Cross and Blais 2012). Regarding conflict regulation, losing government office should therefore make the process of conflict regulation more permissive and improve the chances for a case to be accepted. Consequently, tribunals are expected to accept more cases because the party's move to opposition weakens their ability to downplay conflict as party unity is less central and opposition parties have less to lose than governmental ones.

H3.2 (Government Loss Hypothesis): Tribunals are more likely to accept a case after their party has lost government

\section{Germany as a Least Likely Case for 'Tribunal Politicization'}

When applying rule-of-law principles to intra-organizational settings (Agrast et al. 2010), party tribunals can be seen as formally independent and equivalent to 'state courts' if neither party members in public office nor party leaders are allowed to take a formal role in them. Both the German Party Law and parties' intra-organizational rules fit this description and thereby make Germany a least likely case for finding support for our hypotheses. If we find politicized judicial decision-making in Germany, less regulated intra-party dispute mechanisms are even more likely to be affected by similar dynamics.

The 1967 German Party Law requires tribunals to be independent and prohibits simultaneous membership on a tribunal and in the party executive (Biezen and Piccio 2013: 39-40). In addition, German parties adopted intra-organizational rules that establish the incompatibility of tribunal membership with any party office ( $\$ 14$ Abs 2$),{ }^{4}$ require the election of tribunal members at least every two or four years by the party congress, guarantee the right to replacement of a judge given suspicion of bias ( $\$ 14$ Abs 4), and oblige judges to recuse themselves in case of any conflict of interest. Further the party statutes

\footnotetext{
${ }^{4}$ This also includes public office, central office and any employee of the party or any of its organs. Further they must not receive a salary from the party in any form
} 
point out that the party does not pay judges and the party only covers judges' expenses (e.g. travel costs, accommodation and food) These regulations intend to ensure tribunals' neutrality and their efficient decision-making that should be unaffected by political influences, strategic considerations or other sources of bias unrelated to the nature of the case. ${ }^{5}$ The only criteria by which tribunals decide to accept or reject cases should be procedural.

Germany's strict legal environment is particularly relevant in the acceptance stage. Party statutes clearly outline and limit the possibilities for tribunals to reject a case without opening a hearing, and initiators can challenge the tribunal's decision to reject a case and request a reassessment. German tribunals can use three main but narrowly circumscribed justifications to reject a case: formal mistakes, cases outside tribunal's jurisdiction, and cases without merit. First, rejecting cases due to formal mistakes usually result from missing official deadlines or from providing incomplete claims. Second, tribunals reject cases if the plaintiff's claim lies outside its jurisdiction or the plaintiff did not follow the correct legal path through lower-level tribunals. Third, tribunals perceive the plaintiff's claim to be without merit as they see no legal basis for the complaints in the party statutes or the plaintiffs fail to clearly justify the legal basis of their complaint. Particularly, tribunals' leeway in interpreting the merit of claims opens up space for political considerations.

Covering all main parties constituting the German party system over an extensive time period has several methodological advantages regarding our ability to test our hypotheses due to the composition of the resulting sample of tribunal decisions and the contextual conditions in which these decisions were made (Slater and Ziblatt 2013: 1311-13). Neither the 1967 Party Law nor the parties' statutes implementing it have made significant changes since its introduction, providing constant core procedural requirements for tribunals' decisions overtime and across parties. As our parties cover a wide spectrum of intraorganizational decision-making cultures, we therefore also cover a wide a variety of tribunal submissions. This variation enhances our sample's representativeness regarding the types of

\footnotetext{
5 A "party tribunal" for conflict regulation that is chaired by the party leader or run by members of the executive would not qualify as the equivalent of a "court" since it lacks formal independence from those who hold core powers in the party. Such structures would qualify as hierarchical and leadership controlled instead (see Bolleyer et al. 2017).
} 
conflicts parties experience and the diverse strategies of dealing with them. Analyzing a broad and representative sample is particularly important, as existing research tends to focus on conflict and its regulation in particular arenas (e.g. government coalitions). Broader studies of party conflict tend to focus on particularly visible cases of conflict within new or highly factionalized parties, which are unlikely to be representative of day-to-day intraorganizational conflict regulation in mainstream parties. ${ }^{6}$ This is problematic as intra-party conflict and how parties deal with it tends to be problematized in the media as reporting in the German local and national print media illustrates. ${ }^{7}$ Finally, tribunal documentation is available for an ideologically diverse set of parties up to a 48-year period (1967-2015). During this period parties joined and left national government, experienced electoral victories and defeats and repeatedly revised their party programs, allowing us to test the influence of the core variables in our theoretical framework across parties and over time.

\section{Data, Coding and Measurement}

Our analysis covers all cases of parliamentary parties' national tribunals decided since the introduction of the 1967 German Party Law until 2015. ${ }^{8}$ Tribunal documentation about cases in the Greens, CDU, CSU, SPD and FDP was compiled by the Institut für Deutsches und Internationales Parteienrecht und Parteienforschung (PRuF) at the University of Dusseldorf. ${ }^{9}$ Tribunal documentation for the Left Party was taken from its own website. ${ }^{10}$ To test our

\footnotetext{
${ }^{6}$ Prominent examples are the Dutch List Pim Fortuyn (Reuter 2009; de Lange and Art 2011), New Democracy in Sweden (Aylott 1995; Bale and Blomgren 2008; Jungar 2013), the Spanish UCD (Gunther and Hopkin 2002) or the Italian Christian Democrats (Bardi 1996; Boucek 2012 and 2009).

${ }^{7}$ See, for instance, for membership exclusion: Parteiausschlussverfahren: So funktioniert der Rauswurf, Der Stern, January 21 2008; Wie funktioniert eigentlich ein Parteiausschluss? Focus, August 29 2010; SPD will Ausschlussverfahren verkürzen, Frankfurter Allgemeine Zeitung, September 2 2010;

Parteiausschlussverfahren: Sarrazin darf in der SPD bleiben, Süddeutsche Zeitung, April 22 2011, Edathy darf in der SPD bleiben, Spiegel Online 2016, Februar 122016

For other organisational questions: CDU muss Wahl nicht wiederholen, Nordwest Zeitung, July 02 2005; Wahlanfechtung scheitert - FDP Schiedsgericht erklärt Stellvertreter-Wahl aber für unzulässig, Neue DeisterZeitung, November 12 2009; Vorstands-Wahl der Wallerfanger Linken wird wiederholt, Saarbrücker Zeitung, July 11 2010; Intrigen in der Duisburger CDU, Der Westen, April 14 2011; Parteigericht: Wahl zum AfDVorstand ist doch ungültig, Berliner Morgenpost, Feburary 062017

${ }^{8}$ The CDU, SPD and FDP existed prior to 1967 . Their statutes prior to the law show that party tribunals were already part of their repertoire of conflict regulation (Bolleyer et al 2018).

${ }^{9}$ Institut für Deutsches und Internationales Parteienrecht und Parteienforschung Schiedsgerichtsurteile der obersten Parteischiedsgerichte (PRuF) http://docserv.uni-duesseldorf.de/search/search-judgment.xml

10 Die Linke. Beschlüsse der Bundesschiedskommission http://www.die-linke.de/partei/weiterestrukturen/gewaehlte-gremien/schiedskommission/beschluesse-der-bundesschiedskommission/
} 
hypotheses, we created a new dataset based on the tribunal documentation just described. The high level of formalization and documentation of each tribunal case allowed for straightforward and unambiguous coding decisions. ${ }^{11}$

Coding our dependent variable, whether a case was accepted or rejected, was straightforward as tribunals have to provide a written justification of each rejection to the initiator, which explains which procedural requirement the claim did not fulfill. We identified a case as "rejected" if trial documentation highlighted one of the three reasons discussed above; in other words, when tribunals argued that a claim was incomplete (formal error), inadmissible (outside the tribunal's jurisdiction), or without legal merit. Our results thus indicate why tribunals are more likely accept, or conversely, less likely to reject cases.

To test our two vote logic hypotheses, we calculate the Vote Loss variable on the basis of the ParlGov database (Döring and Manow 2016) by taking the absolute difference in vote shares in the past two elections. For example, if a party gains 20\% in 2013 and $25 \%$ in 2010 we would code a $5 \%$ vote loss for all cases after the 2013 election. When parties gain votes, we code a zero. Finally, we construct Time to Election variable that counts the days until the next election. It reaches $(0)$ on the day of the election and is reset at the time until the next election approaches on the day after the election.

Our second explanatory variable, Policy Disagreement (H2), is Giebler et al's Programmatic Clarity (PC) Index $(2015,2018)$, which builds on the Comparative Party Manifesto (CMP) data (Volkens et al 2016). The PC index captures how clearly parties state their positions in thirteen different policy areas by summing the number of positive and negative towards any of the thirteen areas in a given election. The more unambiguously positive or negative a

\footnotetext{
${ }^{11}$ In all three parties, in order to start a tribunal case the initiator must provide the following information in written form: (1) Name, address and further contact details of initiator, (2) Name and address of the defendant, (3) Clear, unambiguous claim and (4) Reasons for the initiative including a description of the events based on which accusations are made. Once the tribunal receives the claim it reviews the case and either accepts it, leading to a hearing, or rejects the case based on lack of merit or failure to comply with all formal requirements. In case of rejection, the jury is required to send all participants a written justification. It has to include the following information: the evidence provided related to the case and a justification of the tribunal decision with reference to the same evidence. Further, it needs to stress that plaintiff can appeal the initial rejection if they wish to do so.
} 
party's election manifesto describes a particular policy position, the higher their index score, which varies between " 0 " and " 1 ". The weight of each policy area in the index derives from the number of statements all parties dedicate towards that area in a given election. ${ }^{12} \mathrm{We}$ assign the value from the latest available election to each case.

We capture the governmental dynamics of our office logic with two dummy variables: first, Government Status (H3.1) distinguishes cases in parties in government (1) from those in opposition parties (0). Second, Government Loss (H3.2) codes the first year after a party loses governmental power as (1) and the remaining years as (0).

Our first control variable assesses whether the case brought forward was an appeal or not. Most initiators likely appeal after the party tribunals rejected their original cases due to technical inadequacies, and we thus expect a higher acceptance rate of appeals.

Second, our Subject variable controls whether the case covers organizational challenges (1) or membership expulsion (0). As the latter can be essential to sustain the organization's integrity and is less costly for the organization to implement we expect that organizational challenges are more often rejected by tribunals (Cross and Katz 2013: 181).

Third, we control for the role of the initiator within the party. Classical works predict an 'iron law of oligarchy' (Michels 1962: 64, 70; Duverger 1964) that would seem to suggest that cases brought forward by party elites, that is public and party office-holders, should be more likely to get through the acceptance stage than cases initiated by rank and file members.

Fourth, we include the parties' ideological left-right position using the rile score provided by the Comparative Party Manifesto (CMP) data (Volkens et al 2016). By combining scores from

\footnotetext{
${ }^{12}$ Thus, even if a party's manifesto reaches extreme ambiguous or unambiguous scores in a policy area, but the party itself and other parties dedicate little attention to that area overall, the party's index score will hardly be affected.
} 
different policy categories presented in the manifesto it provides an estimate of the ideological position of the party along a general left-right scale with a high and positive score indicating more right-wing parties and low and negative score more left-wing parties. As already outlined the formal rules regulating tribunals are very similar across parties but case acceptance might also be influenced by party membership's generalized values reflected in the party's manifesto. Tribunals in parties on the ideological left should accept more cases because their post-materialist worldview usually suggests openness to challenge authority. In contrast, tribunals in more conservative and traditional parties should be less likely to accept cases. ${ }^{13}$

Fifth, party age, measured in years, distinguishes between more institutionalized parties and younger ones with a high influx of new members. More institutionalized parties can afford to accept more cases as they pose lower threats to party survival. Finally, we control for the number of party members. Larger parties feature more members and more diverse opinions. They may thus be more selective in which cases they accept than their smaller counterparts as the overall case load and level of internal disagreement should increase as membership increases. However courts only have a limited capacity to deal with cases so they will try to reduce the number of cases as much as possible by rejecting them. We derive membership figures from the MAPP project database (Spier 2014). We log both party age and absolute membership size as these variables skew strongly to the right side of the distribution.

Our online appendix includes a table with summary statistics and the bivariate correlations between all explanatory variables in our data.

\footnotetext{
${ }^{13}$ One could argue that while in Western European post-materialist parties often tend to the economic left, more traditional positions need not necessarily be placed on the economic right. For example liberal parties with economically conservative positions frequently pursue very progressive societal polices. Similarly, some left parties, especially traditional communist parties, might be societally conservative. In order to capture this we also ran a model using the Society (Progressive - Conservative) variable suggested by the CMP (see table 5 in the online appendix). The variable is not statistically significant and does not affect our conclusions.
} 


\subsection{Overview of Tribunal Cases}

Table 1 gives an overview of cases submitted by party since 1967 (introduction of party law) or since their formation, in the case of new parties. More particularly, it shows how many made it to the decision stage.

Table 1: Tribunal Decisions in German Parties

\begin{tabular}{|c|c|c|c|c|}
\hline $\begin{array}{l}\text { Party } \\
\text { Name }\end{array}$ & $\begin{array}{l}\text { Period } \\
\text { covered }\end{array}$ & $\begin{array}{c}\text { No. of Approval } \\
\text { Stage Cases }\end{array}$ & $\begin{array}{l}\text { No. of Decision } \\
\text { Stage Cases }\end{array}$ & $\begin{array}{c}\text { Share of Decision } \\
\text { Stage Cases }\end{array}$ \\
\hline CDU & $1967-2015$ & 329 & 245 & 74.47 \\
\hline CSU & 1967-2015 & 102 & 72 & 70.59 \\
\hline FDP & $1967-2015$ & 98 & 88 & 89.80 \\
\hline Greens & $1980-2015$ & 92 & 76 & 82.61 \\
\hline Left & 2007-2015 & 114 & 75 & 65.79 \\
\hline SPD & $1967-2015$ & 353 & 240 & 67.99 \\
\hline Total & $1967-2015$ & 1088 & 796 & \\
\hline
\end{tabular}

Figure 1 displays the acceptance rate over ten five-year periods by party. It becomes immediately apparent that our data do not only contain differences between parties but vary substantially over time. No consistent trend across parties emerges. Newly founded parties such as the Greens and the Left see a considerable increase in the number of cases accepted by their tribunals in the second period after they enter our sample. Yet we see a similar uptick in the Social Democrats' accepted cases in their second period. Clearly, the Social Democrats were a relatively more established party in the second half of the 1970s. Moreover, the increase in accepted cases for the Greens is far less steep than the increase for Social Democrats and the Left. In contrast, the CDU, the CSU, and the FDP experience far milder changes in the number of accepted cases. 


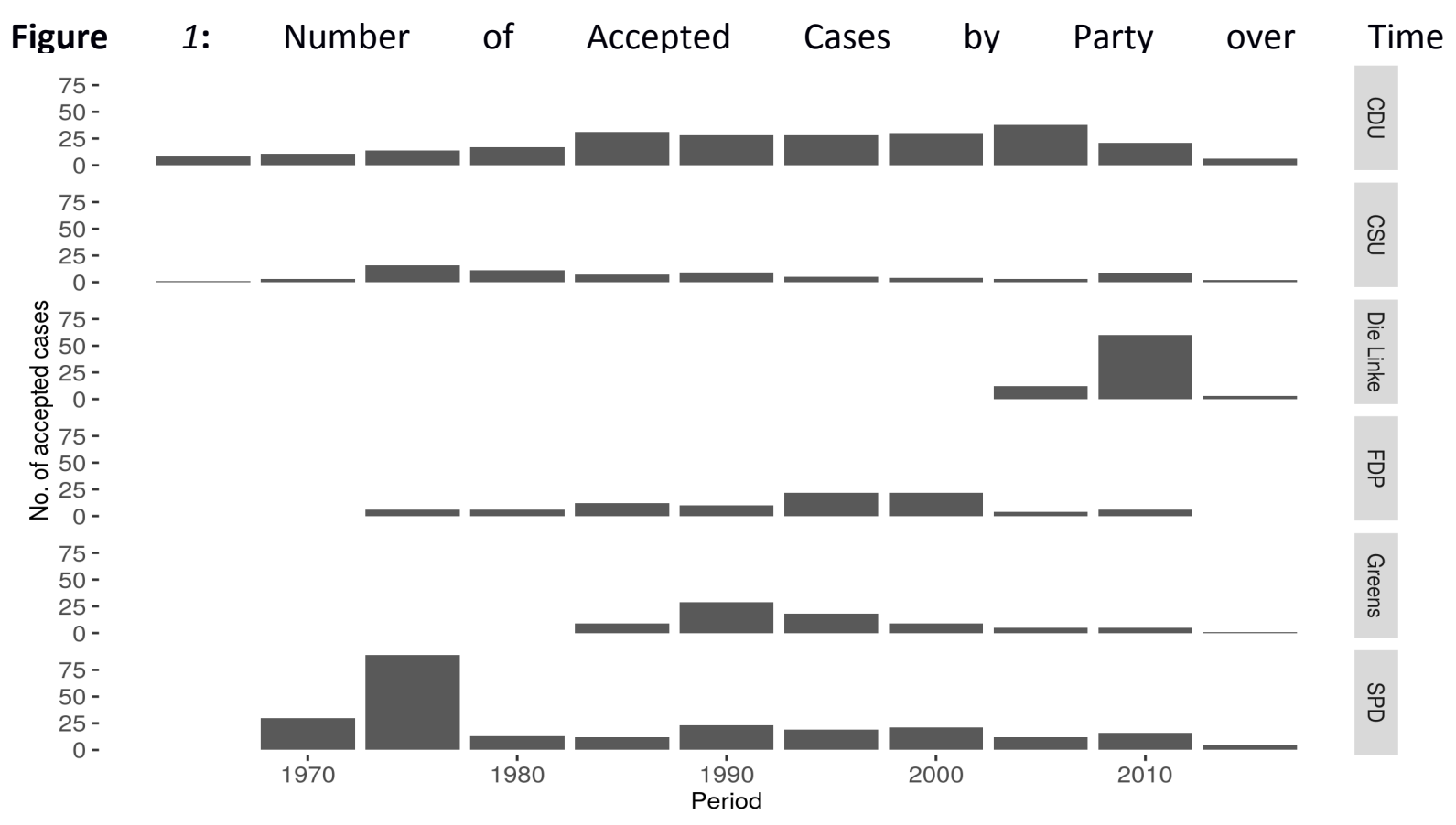

\section{Findings}

We estimate the likelihood of acceptance - or the inverse of rejection - by using a logit model with random intercepts for each party. As Figure 1 revealed substantial differences between parties, the random intercepts help us capture residual variance not picked up by our controls. ${ }^{14}$ Overall, we find strong support for a systematic operation of the political logic in the acceptance stage of party tribunal cases in line with our theoretical expectations. Table 2 displays our regression models.

Model 1 only introduces the control variables (base model), while Models 2-4 add variables associated with each of our hypotheses. Model 5 combines all hypothesis tests into one model. In Models 2-4, we find strong support for each of our vote, policy, and office arguments. Tribunals of parties that lost votes in the last election tend to accept a higher share of cases as expected by H1.1. Similarly, tribunals tend to reject more cases as election time approaches in line with H1.2. Turning to the policy logic, tribunals accept fewer cases when their parties' election manifesto displays greater policy agreement. Conversely,

\footnotetext{
${ }^{14}$ We also tried party fixed effects models, which did not change our conclusions.
} 
tribunals of parties with high disagreement over important policies reject fewer cases as expected by $\mathrm{H} 2$ (Model 3). Regarding the office logic, we find mixed results in Model 4. Parties in government are associated with a greater acceptance rate, or lower rejection rate, of cases relative to opposition parties. While in line with our expectation in H3.1, the estimated effect fails to reach conventional levels of statistical significance. However, the office logic clearly plays out in the context of H3.2. as tribunals in parties that recently lost governmental power are far more likely to accept cases than parties that did not experience such a loss. Except for H3.1, our hypotheses receive support from the data when tested separately - a striking result considering the guidelines set out in the German Party Law and parties' tight regulations.

Our integrated Model 5 continues to lend credibility to our theoretical rationale. Only the estimated effect of our time to election variable drops to the $10 \%$ level. In contrast, policy agreement continues to be statistically significant at the $5 \%$ level and vote loss even improves to be statistically significant at the $1 \%$ level. Given the theoretical and empirical overlap between vote losses and losing governmental power, it is remarkable that we continue to find the expected effects of vote losses and losing governmental power in the joint Model 5. The result suggests an independent effect of recent electoral underperformance even for parties that did not lose office. 
Table 2: Hierarchical Logit Models of Case Acceptance (Rejection) by German Party Tribunals, 19672015.

\begin{tabular}{|c|c|c|c|c|c|}
\hline DV: Case accepted & (1) & $(2)$ & (3) & (4) & (5) \\
\hline Vote Loss & & $\begin{array}{c}0.100 * * \\
(0.041)\end{array}$ & & & $\begin{array}{c}0.116 * * * \\
(0.043)\end{array}$ \\
\hline Time to Election & & $\begin{array}{c}0.037^{* *} \\
(0.018)\end{array}$ & & & $\begin{array}{l}0.030 * \\
(0.018)\end{array}$ \\
\hline Policy Agreement & & & $\begin{array}{c}-2.252^{* *} \\
(1.076)\end{array}$ & & $\begin{array}{c}-2.207^{* *} \\
(1.092)\end{array}$ \\
\hline Government Party & & & & $\begin{array}{c}0.154 \\
(0.170)\end{array}$ & $\begin{array}{c}0.162 \\
(0.182) \\
\end{array}$ \\
\hline Government Loss (t-1) & & & & $\begin{array}{c}2.289^{* *} \\
(1.027)\end{array}$ & $\begin{array}{c}2.115^{* *} \\
(1.033)\end{array}$ \\
\hline Appeal & $\begin{array}{c}0.910 * * * \\
(0.181)\end{array}$ & $\begin{array}{c}0.854^{* * *} \\
(0.183)\end{array}$ & $\begin{array}{c}0.858^{* * *} \\
(0.183)\end{array}$ & $\begin{array}{c}0.873^{* * *} \\
(0.181)\end{array}$ & $\begin{array}{c}0.748^{* * *} \\
(0.187)\end{array}$ \\
\hline Subject Matter & $\begin{array}{c}-0.513^{* * *} \\
(0.166)\end{array}$ & $\begin{array}{c}-0.521^{* * *} \\
(0.168)\end{array}$ & $\begin{array}{c}-0.516 * * * \\
(0.167)\end{array}$ & $\begin{array}{c}-0.532 * * * \\
(0.167)\end{array}$ & $\begin{array}{c}-0.548^{* * *} \\
(0.168) \\
\end{array}$ \\
\hline Initiator & $\begin{array}{c}0.245 \\
(0.165)\end{array}$ & $\begin{array}{c}0.271 \\
(0.167)\end{array}$ & $\begin{array}{c}0.228 \\
(0.165)\end{array}$ & $\begin{array}{c}0.245 \\
(0.165)\end{array}$ & $\begin{array}{c}0.259 \\
(0.167) \\
\end{array}$ \\
\hline Ideology (Left-Right) & $\begin{array}{c}0.014 * * * \\
(0.004)\end{array}$ & $\begin{array}{c}0.014 * * * \\
(0.004)\end{array}$ & $\begin{array}{c}0.010^{* *} \\
(0.004)\end{array}$ & $\begin{array}{c}0.013^{* * *} \\
(0.004)\end{array}$ & $\begin{array}{c}0.010^{* *} \\
(0.005)\end{array}$ \\
\hline Party Age (log) & $\begin{array}{c}0.225^{* *} \\
(0.113)\end{array}$ & $\begin{array}{c}0.151 \\
(0.116)\end{array}$ & $\begin{array}{c}0.131 \\
(0.121)\end{array}$ & $\begin{array}{c}0.169 \\
(0.118)\end{array}$ & $\begin{array}{c}-0.008 \\
(0.131) \\
\end{array}$ \\
\hline Membership Size (log) & $\begin{array}{c}-0.538 * * * \\
(0.106)\end{array}$ & $\begin{array}{c}-0.522^{* * *} \\
(0.106)\end{array}$ & $\begin{array}{c}-0.451 * * * \\
(0.112)\end{array}$ & $\begin{array}{c}-0.518 * * * \\
(0.107)\end{array}$ & $\begin{array}{c}-0.408^{* * *} \\
(0.116)\end{array}$ \\
\hline Constant & $\begin{array}{c}6.659 * * * \\
(1.074) \\
\end{array}$ & $\begin{array}{c}6.372 * * * \\
(1.075) \\
\end{array}$ & $\begin{array}{c}7.743^{* * *} \\
(1.244) \\
\end{array}$ & $\begin{array}{c}6.529 * * * \\
(1.087) \\
\end{array}$ & $\begin{array}{c}7.272^{* * *} \\
(1.225) \\
\end{array}$ \\
\hline Observations & 1,045 & 1,044 & 1,044 & 1,045 & 1,044 \\
\hline Variance (Party RE) & 0 & 0 & 0 & 0 & 0 \\
\hline Log Likelihood & -565.814 & -559.115 & -562.326 & -560.697 & -552.315 \\
\hline$A I C$ & $1,147.628$ & $1,138.230$ & $1,142.653$ & $1,141.395$ & $1,130.629$ \\
\hline
\end{tabular}

${ }^{*} \mathrm{p}<0.1 ; * *<<0.05 ;{ }^{* * *} \mathrm{p}<0.01 ;$ Standard errors in parentheses.

The estimates of our controls reveal mixed results. In line with existing expectations, appeals are more likely to make it through the approval stage, as are cases of membership expulsion (the baseline category in the subject variable). ${ }^{15}$ The estimated effect of party left-

\footnotetext{
${ }^{15}$ We also tested whether our strategic logic differs for organizational challenges over membership expulsions by interacting each of our main explanatory variables with the subject dummy. We estimated likelihood ratio tests by comparing the interaction models, reported in the online appendix, and the simpler models reported in Table 2. On the basis of these tests, we conclude that our hypotheses have similar effects in organizational and expulsion cases.
} 
right positions is positive and statistically significant across all our specifications. This rather counterintuitive result suggests that more conservative parties tend to accept cases more easily than progressive ones, or vice versa, that courts in more progressive parties tend to reject cases more easily than conservative ones. Possibly, conservative parties do not only propagate law and order in their policies but also respect these values in the intra-party arena allowing for case to be heard. Additionally, tribunals of larger parties consistently seem to accept cases at lower rates than tribunals of smaller parties. Although party elites have a slightly higher likelihood of seeing their cases accepted we cannot reject the null hypothesis of no difference between elites and normal party members. The effect of party age is inconsistent. In only one out of five specifications is the estimate of party age positively and statistically significantly related to higher rates of acceptance, and thus negatively related to rejections. Yet it in the remaining models it is not statistically significant and suggests that younger parties tend to reject fewer cases in Model 5. Importantly, our variables pick up all relevant differences between parties. The estimated variance of the party random effects is consistently zero. In fact, regular logit models without random effects return the same results (see Table 4 in the online appendix). 
Figure 2: Predicted changes in probability of case acceptance/rejection

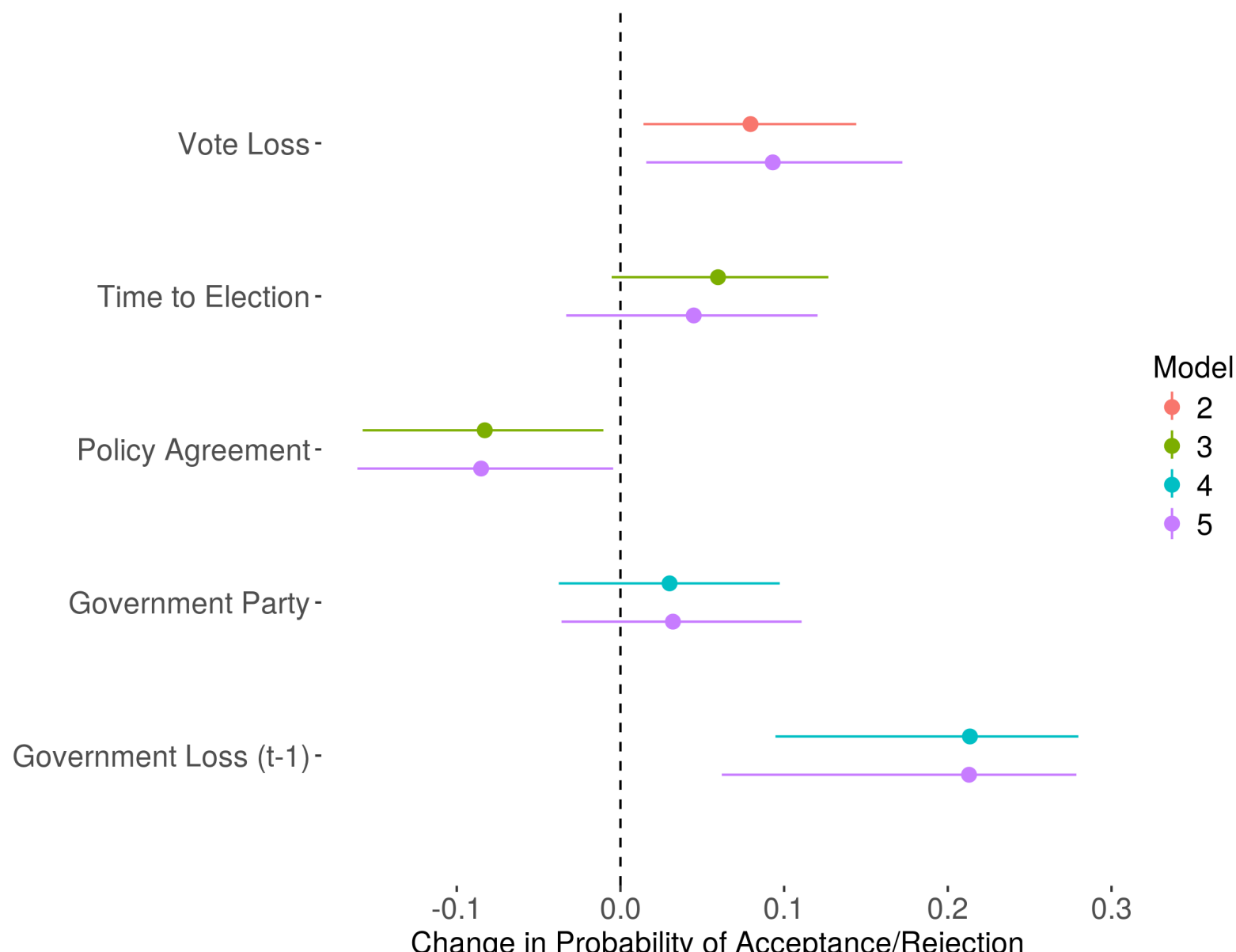

Change in Probability of Acceptance/Reiection

Having discussed the general direction of our predicted effects, we now present their estimated substantive size. Figure 2 portrays the predicted change in probability of case acceptance (rejection) when moving the respective variable from one standard deviation below its mean to one standard deviation above its mean while holding all other variables at their means or modes. In the case of our two categorical variables, government party and loss, we change their value from 0 to 1 . The Figure compares the effects from Models 2-4 to the joint model (5) for each explanatory variable.

Losing four percentage points in vote shares relative to the last election, increases the case acceptance rate by about ten percentage points. Similarly, increasing the time until the next election from a little below a year to about three years, increases the likelihood of case acceptance by about 5 percentage points. Moving from a party with low to one with a high 
programmatic coherence results in a ten-percentage point decrease in the likelihood of accepting a case. Participating in government has only a negligible effect on the likelihood of case acceptance and even approaches zero in Model 5. In contrast, losing access to governmental office clearly exerts the strongest effect among our explanatory variables and increases the probability of case acceptance by about 20 percentage points.

To put these numbers into context, consider the CDU before and after the 1998 federal elections. Helmut Kohl and his party suffered a 6.3 percentage point decrease in vote share and lost government power. Our model thus predicts that the number of accepted cases should rise by a factor of 1.35 from $1997 / 1998$ to $1999 / 2000 .{ }^{16}$ An additional five-per cent increase is predicted because we move from a time close to the election to a year in which the next election is still years away but the time to election effect is offset by the CDU's new status as an opposition party, which accepts fewer cases than government parties. Effectively, our model points in the right direction but overpredicts the actual increase as the observed rate of accepted cases rises from $82 \%$ in $1997 / 1998$ to $93 \%$ in $1999 / 2000$, an increase of only $13 \%$. When we compare the full legislative periods from 1995-1998 and 1999 to 2002, our model predicts an increase in the acceptance rate by $30 \%$ as the decreasing effect of time to election averages out. We observe that the CDU tribunals accepted almost 19\% more cases after 1998 than in the four years up to the election.

In essence, our findings suggest that strategic considerations related to parties' attempts to achieve central goals -votes, policy, and office - affect whether tribunals are likely to deal with instances of conflict and decide on them or avoid making decisions on them altogether.

\section{Conclusions}

The paper explores theorizes and empirically examines how political dynamics affect political parties' internal conflict regulation mechanisms and thereby contributes to a growing literature on intra-party conflict, that - to date - has been primarily interested in

\footnotetext{
${ }^{16}$ The prediction consists of a $15 \%$-increase from losing $6 \%$ of the vote share and a $20 \%$ increase from losing government power.
} 
how parties resolve conflict in particular areas (e.g. in government coalitions), of a particular type (e.g. factionalism) or within particular parties (e.g. new parties) (e.g. Boucek 2009; 2012; Bäck 2008; Deschouwer 2008; Giannetti and Benoit 2008; Maor 1992; Scarrow 2005; Seeleib-Kaiser 2010). Day-to-day mechanisms of conflict regulation and their working processes that tend to be hidden - have received much less attention though case studies of party decline and disintegration suggest their importance for assuring the on-going functioning of parties (e.g. de Lange and Art 2011; Bolleyer 2013; Bolleyer et al 2017). Building on the literature of politicization in public court systems, we propose a new theoretical framework on the operation of intra-party tribunals centered on the core party goals of vote maximization, policy implementation and office holding (Müller and Strøm 1999), and derive five hypotheses on the acceptance and rejection of cases, which we test against novel case data from the highly regulated and legalistic German party tribunal system between 1967 and today.

Our empirical analysis supports our conjectures that tribunals more easily approve cases after lost of votes (H1.1) and tend to accept fewer cases as federal elections approach (H1.2). Further tribunals in ideologically highly coherent parties are less likely to accept

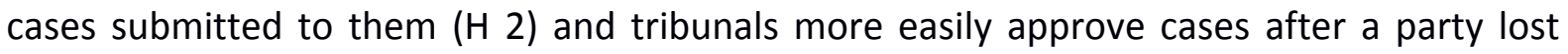
government office (H3.2). Finally, we reject the hypothesis that tribunals of government parties tend to accept fewer cases than their opposition counterparts.

In sum, these findings suggest that strategic considerations related to parties' attempts to achieve their central goals -votes, policy and office- affect whether tribunals accept cases or not. In line with the existing literature (Müller and Strøm 1999) we find party tribunals to be influenced by all three party goals rather than any specific one. Moreover, our findings indicate that the formal requirements that dictate political neutrality have little bite. This is a striking result given that the leeway for tribunals to reject cases for reasons other than procedural violations should not exist. Thus despite the high legalization of intra-party conflict regulation in German parties, political pressures and parties' strategic considerations as theorized above still play a role in whether or not tribunals deal with a conflict in the first place or not. 
More broadly speaking our findings further highlight the importance of political dynamics in the working of party conflict regulation and stress that the politicization of party tribunals should not be underestimated, even when party procedures replicate rule of law standards as they have to under German party law. To put our findings on a more general footing, future research could apply our theoretical argument more broadly and test it in legal settings that also legally require internal party tribunals, for example Czech Republic, Romania and Portugal (Biezen and Piccio 2013), as well as parties that have introduced independent tribunals voluntary such as the Liberal Democrats or Greens in the UK (Bolleyer et al 2018). More specifically, future research should also focus on how to improve the neutrality requirement within parties or more clearly set out the limits of such an approach. This leads to important normative questions raised by our findings that challenge the political neutrality of the tribunals. As stressed earlier the ability of parties to manage and ultimately resolve internal conflict is not only vital for their organizational survival but also to achieve their functions within the political system. Here the tribunals can make a substantial contribution. However the political logic adopted by tribunals also entails clear risks. Therefore we need to ask to what extent it is possible to effectively transplant court structures into an organizational setting and tribunals' ability to enhance intra-party democracy and electoral fortunes of parties, two goals that are often difficult to reconcile. 


\section{References}

Art, D (2011) Inside the Radical Right: The Development of Anti-Immigrant Parties in Western Europe. Cambridge: Cambridge University Press.

Agrast, M , Botero, J , Ponce, A (2010), WJP Rule of Law Index 2011. Washington, D.C.: The World Justice Project.

Andeweg, R., De Winter, L and Dumont, P (2001) Puzzles of Government Formation; Coalition Theory and Deviant Cases. Abingdon/New York: Routledge

Aylott, N (1995) Back to the Future: The 1994 Swedish Election. Party Politics 1: 419-29.

Bäck, H (2008) Intra-Party Politics and Coalition Formation. Party Politics 14 (1): 71-89.

Bakker, R, Edwards, E, Hooghe, L, Jolly, S, Koedam, J, Kostelka, F, Marks, G, Polk, J, Rovny, J, Schumacher, G, Steenbergen ,M, Vachudova ,M, and Zilovic, M (2015) 1999-2014 Chapel Hill Expert Survey Trend File. Version 2015.1. Chapel Hill, NC: University of North Carolina, Chapel Hill, www.chesdata.eu (last accessed December 2016)

Bale, T and Blomgren, M (2008) Close but No Cigar?Newly Governing and Nearly Governing Parties in Sweden and New Zealand. In: Deschouwer, K (ed.)New Parties in Government: In Power for the First Time. London: Routledge, pp 85-103.

Bardi, L (1996) Anti-party Sentiment and Party System Change in Italy. European Journal of Political Research 29(3): 345-63.

Biezen, I van and Piccio, D (2013) Shaping Intra-Party Democracy: on the Legal Regulation of Internal Party Organizations. In: Cross WP and Katz RS (eds) The Challenges of Intra-Party Democracy. Oxford: Oxford UP, pp. 27-48.

Bolleyer, N (2013) New Parties in Old Party Systems: Persistence and Decline in Seventeen Democracies. Oxford: Oxford UP.

Bolleyer, N, Little C and von Nostitz, FC (2015) Implementing Democratic Equality in Political Parties. Organizational Consequences in the Swedish and the German Pirate Parties, Scandinavian Political Studies 38 (2): 158-178.

Bolleyer,N, Nostitz, FC, Smirnova ,V (2017) Conflict Regulation in Political Parties: An Account of Tribunal Decision-Making, Party Politics, 23(6), 834-847.

Bolleyer, N, Gauja, A, Correa Vila, P (2018) The Spread of Legal Norms within Political Parties. Unpublished Manuscript.

Borz, G and Janda, K (2018) Contemporary trends in party organization: Revisiting intraparty democracy, Party Politics, Online First: 1-6 
Boucek, F (2009) Rethinking Factionalism: Typologies, Intra-Party Dynamics and Three Faces of Factionalism. Party Politics 15(4): 455-85

Boucek, F (2012) Factional Politics: How Dominant Parties Implode or Stabilize. Basingstoke: Palgrave Macmillan.

Burchell,J (2002). The evolution of green politics. Development and change within European Green parties. London: Earthscan

Clark, M (2013). A Lack of Party Unity Can Have a Significant Negative Effect on the Electoral Success of European Parties. EUROPP: European Politics and Policy. http://bit.ly/13zZVTd (last accessed 07.04.2017)

Courtney, J (1995) Do Conventions Matter? Choosing National Party Leaders in Canada. Montreal: McGill-Queen's University Press

Cross, W and Blais, A (2012). Who selects the party leader? Party Politics, 18, 127-150.

Cross. W and Katz, R (2013). The Challenges of Intra-Party Democracy. In: Cross, W. and Katz R. (eds.) The Challenges of Intra-Party Democracy. Oxford: Oxford UP, pp.1-10.

de Lange, S and Art, D (2011)Fortuyn versus Wilders: An Agency-based Approach to Radical Right Party Building. West European Politics 34: 1229-49.

Deschouwer, K (ed) (2008) New Parties in Government. London: Routledge.

Döring, $\mathrm{H}$ and Manow, P (2016). Parliaments and governments database (ParlGov): Information on parties, elections and cabinets in modern democracies. Development version.

Duverger M (1964) Political Parties: Their Organization and Activity in the Modern State. London: Methuen.

Giannetti, D and Benoit, K (eds) (2008) Intra-Party Politics and Coalition Governments in Parliamentary Democracies. London: Routledge

Giebler, H, Onawa, P, Regel, S, and Werner, A (2018) Decline or Change? Party Types and the Crisis of Representative Democracy. In Merkel, W. and Kneip, Sascha (Eds.): Democracy and Crisis Challenges in Turbulent Times. Wiesbaden: Springer VS, 145-175

Giebler, H, Onawa, P, Regel, S, and Werner, A (2015) Niedergang oder Wandel? Parteitypen und die Krise der repräsentativen Demokratie. In: Merkel, W. (Ed.): Steckt die Demokratie in der Krise?. Wiesbaden: Springer VS, 181-220 
Greene, Z and Haber, M . 2015. "The consequences of appearing divided: An analysis of party evaluations and vote choice." Electoral Studies 37: 15-27

Hopkin, J and Gunther, R (2002) A crisis of institutionalization: the collapse of the UCD in Spain. In: Gunther, R., Montero, J. and Linz, J. (eds.) Political Parties: Old Concepts and New Challenges. Oxford University Press, Oxford, UK, pp. 191-232.

Harmel, R and Janda, K (1994) 'An Integrated Theory of Party Goals and Party Change', Journal of Theoretical Politics 6: 259-87.

Hein, M and Ewert, S (2016) How Do Types of Procedure Affect the Degree of Politicization of European Constitutional Courts? A Comparative Study of Germany, Bulgaria, and Portugal European Journal of Legal Studies, Volume 22

Inglehart, R (2008). Changing Values among Western Publics from 1970 to 2006. West European Politics 31 (1-2), 130-146

Janda, K (1990) Toward A Performance Theory of Change in Political Parties Prepared for delivery at the 12th World Congress of the International Sociological Association, Research Committee 18, Session 4, "Modelling Party Change,"Madrid, Spain, July 9-13, 1990

Joondeph, B (2008). The Many Meanings of "Politics" in Judicial Decision Making, 77 UMKC L. Rev. 347, Available at: http://digitalcommons.law.scu.edu/facpubs/35

Jungar, A-C (2013) Keeping the party together: Party leadership and Cohesion in the True Finns and the Sweden Democrats, In: The EUSA Conference, Baltimore, US, 9-11 May.

Kastellec, J and Lax, J (2008), Case Selection and the Study of Judicial Politics. Journal of Empirical Legal Studies, 5: 407-446.

Katz, R and Mair, P (1995) Changing Models of Party Organization and Party Democracy: The Emergence of the Cartel Party. Party Politics 1: 5-28.

Leduc, L (2001) Democratizing Party Leadership Selection, Party Politics 7: 323-41

Lindstädt, R , Slapin, J , and Vander Wielen, R (2011). Balancing competing demands: Position-taking and election proximity in the European parliament. Legislative Studies Quarterly, 36(1), 37-70.

Maor, M (1998) Parties, Conflict and Coalitions in Western Europe. London: Routledge.

Mak, E (2015) "Case Selection in the Supreme Court of the Netherlands - Inspired by Common Law Supreme Courts?", European Journal of Current Legal Issues, 21(1).

Michels R (1962) Political Parties: A Sociological Study of the Oligarchical Tendencies of Modern Democracies. New York: Free Press. 
Mudde, C (2007)Populist Radical Right Parties in Europe. Cambridge: Cambridge University Press.

Müller-Rommel, F and Poguntke, T (eds)(2002) Green Parties in National Governments. London: Frank Cass.

Pedersen, H (2012) What do Parties Want? Policy versus Office. West European Politics, $35: 4,896-910$

Provine, D (1980). Case selection in the United States Supreme Court. Chicago: University of Chicago Press.

Rahat, G (2013) What is Democratic Candidate Selection? In: Cross, W. and Katz, R. (eds) The Challenges of Intra-Party Democracy. Oxford: Oxford UP, pp. 136-149.

Reuter, G (2009) Rechtspopulismus in Belgien und den Niederlanden. Wiesbaden: VS Research.

Richards, M and Kritzer, H (2002) Jurisprudential Regimes in Supreme Court Decision Making. American Political Science Review , 96(2), pp.305-20.

Scarrow, S (2005) Political Parties and Democracy in Theoretical and Practical Perspectives: Implementing Intra-Party Democracy. Washington: The National Democratic Institute.

Seeleib-Kaiser, M (2010) Socio-Economic Change, Party Competition and Intra-Party Conflict: The Family Policy of the Grand Coalition. German Politics 19(3-4): 416-428.

Sandri, G and von Nostitz, F-C (2015) Are they in or are they out: The diversity of forms of political participation and its regulation across party organizations, Paper presented at APSA Annual Conference, September 3-6, San Francisco CA, United States.

Sheldon, C (1970) The Supreme Court: Politicians in Robes. Beverly Hills (Calif): Glencoe Press

Skjaeveland, A (1999). A Danish party cohesion cycle. Scandinavian Political Studies, 22(2), 121-136.

Slater, D and Ziblatt, D (2013) The Enduring Indispensability of the Controlled Comparison, Comparative Political Studies, 46 (10): 1301-27.

Smith, R and Gauja, A (2010) Understanding Party Constitutions as Responses to Specific Challenges, Party Politics 16 (6): 755-75.

Spier, T (2014), ‘Party Membership Figures. Germany 1945-2013'. MAPP Project Data Archive [www.projectmapp.eu]. 
Stone Sweet, A ( 2000) Governing with Judge Constitutional Politics in Europe. Oxford: Oxford University Press

Volkens, A, Lehmann, P, Matthieß, T, Merz, N, Regel, S and Werner, A (2016): The Manifesto Data Collection. Manifesto Project (MRG/CMP/MARPOR). Version 2016a. Berlin: Wissenschaftszentrum Berlin für Sozialforschung (WZB)

Müller, W and Strøm, K (1999) Policy, Office, or Votes? How Political Parties in Western Europe Make Hard Choices. Cambridge: Cambridge University Press

Zariskia, R (1965) Intra-Party Conflict in a Dominant Party: The Experience of Italian Christian Democracy. The Journal of Politics 27(1): 3-34

Zorn, C and Bowie, J (2010). Ideological Influence in the Federal Judicial Hierarchy: An Empirical Assessment. Journal of Politics 72(4): 1212-21 